
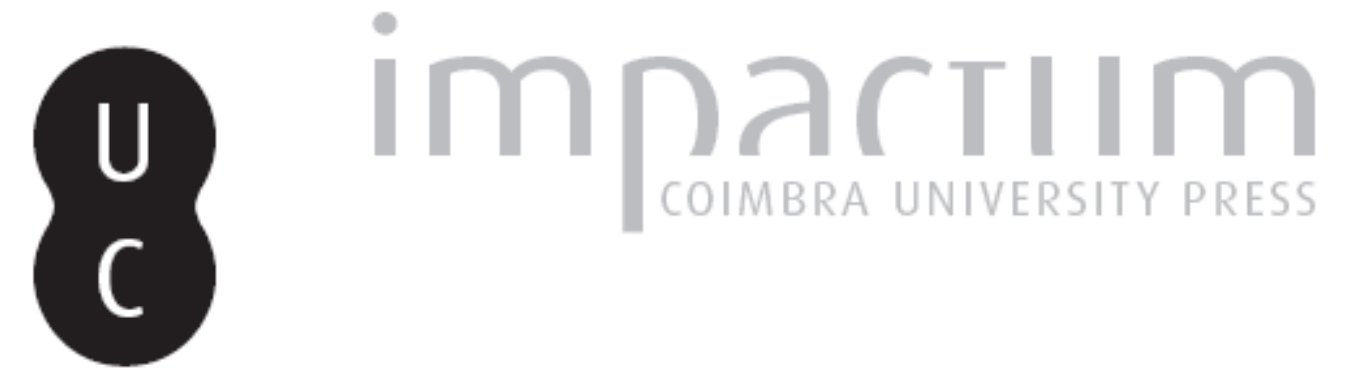

\title{
Xanthippus of Laecedemonia: a foreign commander in the army of Carthage
}

\section{Autor(es): Dantas, Daniela}

Publicado por: Centro de História da Universidade de Lisboa

URL persistente:

URI:http://hdl.handle.net/10316.2/44038

DOI:

DOI:https://doi.org/10.14195/0871-9527_26_6

Accessed : $\quad$ 26-Apr-2023 10:05:49

A navegação consulta e descarregamento dos títulos inseridos nas Bibliotecas Digitais UC Digitalis, UC Pombalina e UC Impactum, pressupõem a aceitação plena e sem reservas dos Termos e Condições de Uso destas Bibliotecas Digitais, disponíveis em https://digitalis.uc.pt/pt-pt/termos.

Conforme exposto nos referidos Termos e Condições de Uso, o descarregamento de títulos de acesso restrito requer uma licença válida de autorização devendo o utilizador aceder ao(s) documento(s) a partir de um endereço de IP da instituição detentora da supramencionada licença.

Ao utilizador é apenas permitido o descarregamento para uso pessoal, pelo que o emprego do(s) título(s) descarregado(s) para outro fim, designadamente comercial, carece de autorização do respetivo autor ou editor da obra.

Na medida em que todas as obras da UC Digitalis se encontram protegidas pelo Código do Direito de Autor e Direitos Conexos e demais legislação aplicável, toda a cópia, parcial ou total, deste documento, nos casos em que é legalmente admitida, deverá conter ou fazer-se acompanhar por este aviso.

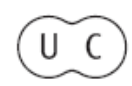




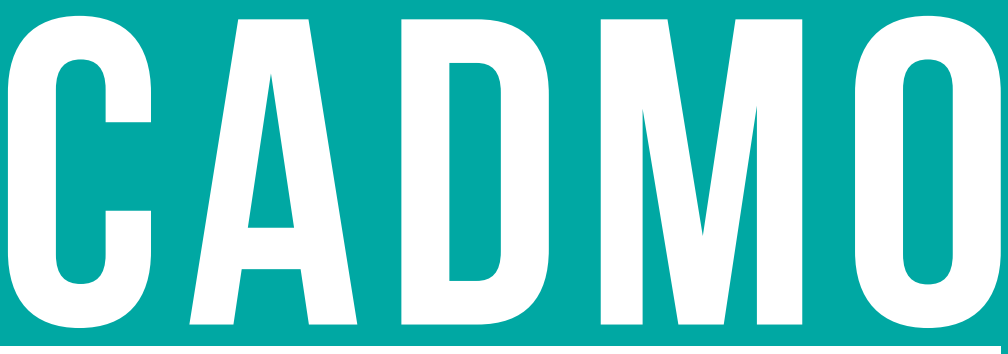

REVISTA DE HISTÓRIA ANTIGA JOURNAL FOR ANCIENT HISTORY

26

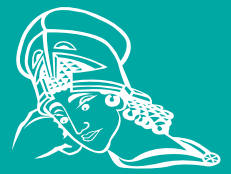

CENTRO DE HISTÓRIA DA UNIVERSIDADE DE LISBOA 2017 


\title{
XANTHIPPUS OF LAECEDEMONIA: A foreign commander in the army of Carthage
}

Daniela Dantas

Centro de História, Faculdade de Letras, Universidade de Lisboa

daniela.m.dantas@gmail.com | @ https://orcid.org/0000-0002-0243-1328

$\begin{gathered}\text { proposta: } \\ \text { submission }\end{gathered} 28 / 12 / 2016$ | $\begin{gathered}\text { aceitação: } \\ \text { acceptance } 20 / 11 / 2017\end{gathered}$

\begin{abstract}
Throughout its History, and especially during the Hellenistic period, Carthage is known to strongly rely on the use of mercenaries. Together with the Libyan and Numidian contingents, these men, who came from the most diverse origins, composed the greater part of Carthaginian armies. However, they are never known to occupy the high ranks of the army, which seem to always belong to a group of the Carthaginian aristocracy that one may call a 'military elite'. In 255 BCE, for the first and only time in records, a foreigner assumes the role of general, granting a victory by the Bagradas river, which ensured the capture of the Roman consul, the defense of the city of Carthage and the Roman retreat of North Africa. The commander is Xanthippus, said of Lacedemonia, unheard of until 255 BCE, disappearing from historical records following that year. This article is an attempt to trace the origins of Xanthippus, as well as his actions during and after the First Punic War, connecting pieces of information in an attempt to understand not only his particular lifecourse, but also to place hypotheses on the journey of mercenaries across the Hellenistic Mediterranean.
\end{abstract}




\section{Keywords}

Xanthippus | Punic Wars | Mercenaries | Carthage.

\section{Resumo}

Ao longo da história, e especialmente durante o período Helenístico, Cartago é conhecida por depender fortemente do uso de mercenários. Juntamente com os contingentes Líbios e Númidas, estes homens, oriundos das mais diversas origens, compunham a maior parte dos exércitos cartagineses. Contudo, nunca surgem como ocupantes dos altos cargos do exército, que parecem pertencer sempre a um grupo da aristocracia cartaginesa a que se pode chamar 'elite militar'. Em 255 a.C., pela primeira e única vez registada, um estrangeiro assume o papel de general, garantindo uma vitória junto do rio Bagradas, que assegurou a captura do cônsul romano, a defesa da cidade de Cartago e a retirada romana do Norte de África. O comandante é Xântipo, dito da Lacedemónia, do qual não se ouve falar até 255 a.C., e que desaparece dos registos históricos após esse ano. Este artigo é uma tentativa de traçar as suas origens, bem como as suas acções durante e após a Primeira Guerra Púnica, ligando fragmentos de informação numa tentativa de compreender não só o seu percurso particular, mas também de colocar hipóteses quanto à jornada dos mercenários através do Mediterrâneo helenístico.

\section{Palavras-chave}

Xântipo | Guerras Púnicas | Mercenários | Cartago.

Throughout its history, and in spite of continual mercenary use, Carthage maintained a tradition of attributing the high ranks of the army to its inhabitants. These men often formed dynasties of what may be called a "military elite". The situation seems to have remained unchanged until the First Punic War. In 255 BCE, for the first and only time during this conflict, a foreigner was made a commander in the army of Carthage. This man was Xanthippus. The only detail in which ancient sources agree regarding his life is the fact that he was a mercenary who came from Lacedemonia. Everything else is either unknown or uncertain. However, in spite of the circumstances surrounding his sudden rise in the military world and his equally sudden disappearance, the sources give us plenty of material for establishing comparisons, in an attempt to draw some conclusions on Xanthippus' life. 
To understand the context in which this warrior is brought to light, one should begin by observing the situation of the war prior to his arrival in North Africa. Rome had successfully besieged the Sicilian city of Akragas in 262 BCE and won the Battle of Mylae in 260 BCE, but not even their subsequent alliance with Hiero II, tyrant of Syracuse, enabled them to expel the Carthaginians out of Sicily or, in the least, to make a determinant stand regarding the war. Thus it seems that Rome attempts to move the axis of war from Sicily to North Africa, something which had been attempted in the previous century by Agathocles to diminish the exertion of war on the island. ${ }^{1}$ In addition, Polybius remarks this moment as a major period of change and reorganisation within the Roman navy, the troops boarding the ships towards North Africa being ready to fight both at sea and land. ${ }^{2}$ A naval battle occurred across Cape Tyndaris, of which Rome comes out as a victor, and the Roman navy could then cross the Mediterranean. For the first time since the beginning of the war, Carthage sees its own territory threatened.

After the defeat in Cape Tyndaris, the remainders of the Carthaginian army were reorganised and the situation was re-evaluated. The Romans didn't seem to be willing to attempt a naval siege of Carthage itself: after the ships landed, the army proceeded to successfully besiege Aspis, and turned it into a centre of operations, using the farmsteads on the outskirts to provide supplies. Between the siege of Aspis and the Battle of the Bagradas River, the Roman army successfully plundered the Carthaginian territories, achieving a considerable amount of both livestock and captives. ${ }^{3}$

This is the context in which Xanthippus comes to our knowledge. The Roman army is divided. Half of the army is sent back to Rome, and the other half, under the command of consul Gaius Atilius Regulus, received orders to remain in North Africa. According to Polybius, Regulus proceeded onto besieging Adys; a battle ensued, and once again the Carthaginian army was defeated, a defeat that would have allowed Regulus' army to freely plunder and attack the settlements

1 D.S. 20.2-3. The expedition had moderate success. Agathocles managed to return to Sicily and rebalance power between the Greeks and the Carthaginians (20.77), but did not fulfil to expel the Carthaginians from the island nor to have any enduring influence in North Africa.

2 Plb. 1.26.

3 Plb. 1.29 . 
nearby, including that of Tunis, considerably close to Carthage. The Punic situation worsened as unspecified elements of Numidian tribes take advantage of the moment and rebel, plundering the countryside farmlands. ${ }^{4}$ The coincidental actions of Romans and Numidians create a logistical problem to Carthage, by cutting the supply sources both for city and countryside inhabitants. ${ }^{5}$

After failed negotiations between the belligerents, the sources say a man named Xanthippus became noticeable inside the army, but they do not agree on how this happens. Polybius says that Carthage sent mercenary recruiters to Greece prior to these occurrences, and Xanthippus came among them. Hearing of the Carthaginian situation, Xanthippus would have analysed their previous defeats and discussed his opinions in front of his comrades; eventually, his words reached the generals, who sent for him and, after further conversation, decided to assign Xanthippus as commander of the army, giving him further responsibility in the approaching conflict.

Appian, however, tells a different version. According to this source, the Carthaginians would have sent recruiters to Lacedemonia, not to bring a fresh group of mercenaries, but with specific orders to request for a commander. Sparta would have then sent them Xanthippus. ${ }^{6}$ Yet another version is told by Diodorus Siculus, in which Xanthippus is presented as a mercenary soldier, who would have urged the generals to give battle and offered himself as a commander. ${ }^{7}$ Cassius Dio mentions his arrival among the allies of Carthage, and that he would have assumed full authority over the whole city. ${ }^{8}$ Cicerus merely refers to Xanthippus as being a Spartan general under the command of Hamilcar Barca.

Neither version agrees on his origins and rank prior to his arrival, nor are they clear. Both Polybius and Cassius Dio seem to imply he did not come from a wealthy or aristocratic background: the former says he comes among the ranks of other mercenaries and apparently distinguishes him by his knowledge of military

\footnotetext{
Plb. 1.31.

5 The fact that Carthage relied mostly on Libyan and Numidian manpower to supply its armies often became problematic, because these communities would occasionally rebel. Raven [1969] 2012, 25.

6 App. Pun. 1.3.

7 D.S. 23.

8 D.C. 11.13.

9 Cic. Off. 3.26 .
} 
tactics and strategy, and in the latter, he is specifically described as being of low birth (Dio mentions Carthaginian bias against Xanthippus, who would have been called a Graecus $^{19}$ ). It is impossible to determine when or where Xanthippus was born, and none of the sources gives us clues about it. Nothing is mentioned on his social origins either, so we are unaware whether he was, or not, a citizen or the son of a citizen, prior to enrolling in the mercenary ranks. Sparta had a tradition of engaging boys in some sort of athletic and military practice at very young ages, namely, when they reached their seventh year. For some centuries, the regular army career in Sparta began when a man turned twenty years old, and could go until his sixtieth year, when he would officially seize his obligations towards the army and enter the Council of Elders. ${ }^{11}$ However, Xanthippus lived in the Hellenistic period. Significant changes had occurred in the Greek city-states, following the lives (and deaths) of Philip and Alexander of Macedonia (although traditional Spartan agoge was not officially abolished until $188 \mathrm{BCE}^{12}$ ).

It is unsure whether Xanthippus was a descendant of citizens. In 1935, Griffith pointed a decreasing number of citizens during the first half of the $3^{\text {rd }}$ century BCE and a decrease in the city's military investment upon the citizens, acknowledging Sparta's infrequent participation in large conflicts, and the growth of mercenary use from $244 \mathrm{BCE}$ onwards, due to Leonidas' intervention. ${ }^{13}$ Citizen or not, Xanthippus was certainly trained in combat, but most importantly, was also well-versed in command; otherwise, the Carthaginian army would have no reason to employ him, a foreigner, in replacement of their own generals. He was likely not a freshly trained recruit, but an experimented warrior. He would have fought in other battles and, most likely, acted as a commander several times prior to the battle of the Bagradas river.

Despite being the commander, he is also presented as having a more active role in battle. Xanthippus might have been around his thirty years of age when the battle of the Bagradas River was fought, making him born slightly before the

10 Earnest 1914 says Dio meant to use the diminutive Graeculus, which is meant to be insulting.

11 Hodkinson 2013, 104-7.

12 It was replaced with the Achaean system by Philopoaemen. Champion 2004, 128-29.

13 Griffith [1935] 2014, 93-96. Trundle highlights the fact that most mercenary companies originating in Greek territory were constituted by great numbers of «outsiders». Trundle 2004, 111. 
beginning of the Pyrrhic War. In a time of endemic war and frequent campaigns amongst the different city states, there would have been many opportunities for Xanthippus to gain practical, strategical and tactical knowledge of war and, since Sparta was not involved in substantial conflicts at the time, probably gained his practice abroad. ${ }^{14}$ Indeed, Polybius mentions he had not only been trained "in the Spartan manner", but also had "considerable experience of warfare", even though he does not proceed to specify. ${ }^{15}$

Appian, who presents him as an envoy of Sparta, is supported by Florus, ${ }^{16}$ but every other source suggests he was but one man among a group of mercenaries. Even though we cannot trace his origins, or how he came to find himself in mercenary ranks (or even whether he was indeed to be considered as a mercenary), there are several studies about the background of Greek Mercenaries in Antiquity. A mercenary fighting for a foreign land would not act as an active political element in the city. This does not mean, however, that mercenaries could not influence the life of a city: on one hand, mercenaries often remained in the cities who hired them for reasonably long periods of time, and in the other hand, they could attain a certain degree of influence themselves, through acquired wealth or citizenship grants. ${ }^{17}$ It is also possible that Xanthippus can trace his origins to a citizen family, or was a citizen himself at some point: Chaniotis mentions a growth of mercenary demand during the Hellenistic period, with a fair supply of available men coming from the Greek city-states, consisting of men dislodged by the many conflicts of the $4^{\text {th }}$ century BCE (among them, the Peloponnesian War). ${ }^{18}$ Luraghi mentions the possibility of some archaic Greek mercenaries to come from aristocratic backgrounds, and it is not impossible to have the same situation in the Hellenistic period. ${ }^{19}$

There is also the matter of career progression and armament. One can argue that a mercenary could start his career in less expensive positions, amongst

14 With the increased use of mercenaries, the armies of hired soldiers acquire greater mobility. Throughout the $3^{\text {rd }}$ century BCE, one can find mercenaries from a multiplicity of origins serving under the same entity. Chaniotis 2002, 99-100.

15 Plb. 1.32. Furthermore, he doesn't explain what is to be considered as the "Spartan manner" in the early 3rd century BCE.

16 Flor. 1.18.2.

17 Granting citizenship to mercenaries is known to have been practiced in Sicily since, at least, the $6^{\text {th }}$ century BCE, during the tyranny of Gelon. De Angelis 2016, 183-85.

18 Chaniotis 2005, 80.

19 As mentioned by Chaniotis, King Leonidas spent part of his adulthood as a mercenary. 
the light infantry, ${ }^{20}$ for example, and, as he gained experience, to progressively improve his position by acquiring equipment through his wages as a mercenary and/or his share of plunder ${ }^{21}$. There is also the matter of Xanthippus' position. If Xanthippus fought as a footsoldier, he fared war during a period of change. The traditional hoplon and spear began to give way to new types of weaponry, especially after the defeat of the Greek alliance by Philip II of Macedonia in Chaeronea, in 338 BCE. This battle is a key representative of the evolution of weaponry and equipment: the hoplite equipment of the $4^{\text {th }}$ and $3^{\text {rd }}$ centuries BCE went through a series of changes due to the influence of Macedonian armies, and Plutarch portrays its evolutions, such as the replacement of the previous spear by the sarissa, and the introduction of a different way to carry the shield, to release both hands to hold the pike. ${ }^{22}$ Plutarch attributes the widespread use of the new typology of weapons to Cleomenes III, but Xanthippus, as a well-travelled mercenary, was most likely already acquainted with them.

Another feature which can be added to the discussion of Xanthippus' status, training and origin is whether he was used to horse-riding. As a mercenary commander, he seems to have enough riding skills to allow him to quickly move through the battlefield, both to be able to communicate orders and to observe the situation. Diodorus describes him as riding throughout the field and even seizing fleeing soldiers, sending them back to the battle. Eventually, due to a remark which might imply lack of bravery (given that he was giving his orders from a horse), he would have dismounted it and proceeded his task on foot. ${ }^{23}$ Diodorus does not mention him as having fought himself in the Carthaginian ranks, though, and certainly does not mention him being trained as a cavalryman.

As far as cavalry is regarded, Sparta had its own tradition. It developed an elite corps of cavalry, consisting in three hundred knights (the Hippeis), elected by

20 There were two main careers for a Hellenistic mercenary: either he fought for a King (with no such thing as 'allegiance' involved) or for a city-state. Oliver 2011, 350, note 351.

21 Luraghi 2006, 24-25.

22 Plu. Cleom. 11.2. Snodgrass 2013, 93. On the evolution of the sarissa and the shield, see Sage 2002a, 169-70; 2002b, 210-11 (also on the cavalry equipment).

23 Sage 2002b, 199, underlines that the Hellenistic armies saw an evolution regarding the position of the commander in battle, with the general placing himself on the «extreme end of the line», for better awareness and control during the conflict. 
three hippagretai, which would control a force of one hundred men each. ${ }^{24}$ There are different views on the meaning of the term hippeis in what regards these men, and Bugh mentions Strabo's quote about the Lacedemonian hippeis, which would not keep horses. Bugh, basing his assertions on Strabo, distinguishes two types of Spartan hippeis, namely those belonging to actual cavalry forces, and the three hundred elite soldiers, which would, in fact, be hoplites. ${ }^{25}$ Regardless, at least from 424 BCE onwards, Sparta did employ cavalry. ${ }^{26}$ Two centuries passed between 424 BCE and the First Punic War, and the different corps of Mediterranean Cavalry evolved. Inheriting the changes introduced by Philip and Alexander of Macedonia, cavalry maintained its importance. The positioning of formations with cavalry on the wings becomes so widely accepted across the Mediterranean that it will be found in both armies during the Battle of the Bagradas, and during Hellenistic reforms, there is also the introduction of a new unit, the cataphract. ${ }^{27}$

It does not seem as if Xanthippus, as a commander, belonged to the ranks of heavy cavalry. One may also ask whose horse he rode. Was it his own horse, was it borrowed from the city of Carthage? Discussing whether Xanthippus was a footsoldier or a cavalryman is especially important in the Carthaginian scenario. Carthage had its own source of supply for horsemen, namely the Numidian cavalry, which provided a very specific sort of light cavalry unit. ${ }^{28}$ One may discuss whether Carthage used mercenary cavalry during the First Punic War. It's never specified by sources, but there are mentions of Carthaginian cavalry; ${ }^{29}$ it is debatable whether it refers to the Numidian horsemen or not. ${ }^{30}$ If Xanthippus was just another mercenary, and not a commander envoy, could he belong in mercenary cavalry units? ${ }^{31}$

24 Hdt. 8.124.3. According to this source, only five places would be vacant each year: the five eldest knights would retire. 1.67.5. X. Lac., 4.3-7. Hinge, 64. As Hinge mentions, these three hundred men would be part of a military elite, which gives significance to Spartan Cavalry.

25 Bugh 25-26.

26 Gaebel 2002, 282.

27 Sage 2002b, 199; 210-11.

28 Str. 17.3. Strabo describes the Maurusians, Masaesylians and Lybians as having very similar lifestyles, dressing in similar fashion and having similar horsemen, who rode small, fast horses, governed with a small rod.

29 Plb. 1.33.

30 The doubt does not remain during the Second Punic War: during his campaign in Gaul, Hannibal is said to have not only Numidian horsemen, but foreign cavalry too (Liv. 21.21-22; 21.46, for ex.). It is thus likely that Carthage did engage mercenary cavalry units during the First Punic War as well.

31 From the $4^{\text {th }}$ century onwards, generals of infantry often rode horses to battle. Wheeler points out an episode which is very similar to that of Xanthippus: Clearchus, a mercenary general, leading his hoplites in horseback, 
It might be noticed that Polybius inserts Xanthippus' history as somewhat of a plot-filler: ${ }^{32}$ the mercenary soldier suddenly appears amongst the ranks, wins an important battle and then disappears, perhaps murdered due to Carthaginian conveniences. It seems as if Xanthippus is introduced as having to fulfil a single role: to win a battle against the Romans in North Africa. This is highly contradictory to his own descriptions of Xanthippus' actions and the reaction of people that surrounded him. It might be added that Xanthippus receives a significant amount of attention from Polybius, more than many of the Carthaginian commanders. Why would Polybius focus on Xanthippus, given that his role in the war is reduced to one single battle ${ }^{33}$ As Bagnall mentions, Xanthippus was accepted and convinced the Carthaginian Senate, as well as the army itself. Men wanted Xanthippus to lead them into battle, and his leadership would have caused a significant rise in the morale. ${ }^{34}$

One point that might be questioned is Xanthippus' prior experience with North African armies. As Bagnall reminds us, Polybius mentions Xanthippus as having trained the army prior to the battle, so, as discussed above, he must have been used to command, and been successful at it. Above all, he must have been acquainted with their fighting system, not only because he seems able to name its flaws, but also due to his knowledge of how to deploy endogenous war unities (such as war elephants and Numidian cavalry) in a battlefield and make the most advantage of them. The Carthaginian army of this period was a very specific type of force to be commanded: it consisted of unities with the most diverse origins (from the Balearic slingers to other Greek Mercenaries like Xanthippus), which had different particularities and uses, and Xanthippus could deploy them and put their specific skills to use in a short period.

According to Appian, Regulus would have learned that Xanthippus was to be the commander instead of the Carthaginian generals. Whether it made him feel differently about his chances in North Africa, it is not known, but perhaps the idea

eventually dismounts and proceeds fighting on foot after being criticised. X. An. 3.4.46-49. Wheeler 2002, 141.

32 Nikos Miltsios points it as being a «twist in the plot», a literary device suitable not only to make the narrative more appealing to the readers, but also to enforce the idea, shared by Polybius, of the importance of individual thought and will as factors of change in the course of History. Miltsios 2013, 39-40.

33 As a suggestion, it might be said that Polybius meant to emphasise the fact that the Roman army was not beaten by the Carthaginians themselves, but by a foreign warrior.

34 Bagnall 1999, 75-76. 
presented by Polybius of a strong, confident army conquering and plundering the land is not accurate. It is certainly not shared by Appian. He describes the Roman army as being in a state of exhaustion, due to the weight they had to carry (including armour), the fatigue of the journey and the conflict itself, and the lack of provisions, which concurred to dehydration (the source mentions issues caused by dust and thirst). The army also endured constant insecurity, given that the "neighbouring heights" harassed them with missiles. Thus there are two very different accounts of the state of mind of both army and commander, one in which Regulus feels confident due to the good progress of the campaign, and another in which there seems to be the need to either retreat or give combat, given the condition of the army. ${ }^{35} \mathrm{He}$ decided to cross the river, apparently as a way to terrify Xanthippus, but most likely due to the need to give battle.

In regard to the battle itself, the following question must be asked: What did Xanthippus do differently from the Carthaginian generals, to ensure such a determinant victory as to force the Roman legions to retreat North Africa? First, one must look at two things: numbers and formation. The Carthaginian army had, according to Polybius, 12000 foot soldiers, 4000 cavalrymen and nearly 100 elephants, whilst Rome had 15000 infantrymen, 500 hundred cavalry. ${ }^{36}$ Thus, Rome had many more infantry soldiers, but Carthage had a significant number of horsemen. Carthage also had the use of elephants, ${ }^{37}$ and Rome had nothing to counter their weight in battle. As for formations, Xanthippus positioned the elephants in the front, the heavy infantry behind the elephants, and both cavalry and light-infantry in the wings. Regulus had the uelites up front, the heavy infantry behind and the cavalry also in the wings, hoping that in this way he would be able to avoid the elephant attacks, which he dreaded above all. ${ }^{38}$ Zonaras mentions one particular change made by Xanthippus regarding the Carthaginian fighting style: he

35 App. Pun. 1.3.

36 The number of horsemen is calculated upon the legion left behind following the departure of Manlius Vulsus Longus, the consul who reached North Africa with Xanthippus.

37 The fact that Xanthippus was successful in his deployment of the paquiderms is particularly significant when one observes the negative results they often bring; it is also noticeable how elephants cannot always be used (Plb. 1.33 speaks of a Roman retreat to high terrain, which prevents Elephant charge) and how, as mentioned, Xanthippus' first measure was to bring the battle to an open field, positioning them ahead of the heavy infantry. Wylie 2009, 127-29.

38 Plb. 1.33. 
seized fight in high regions and brought it to plain terrain, so as to make the best use of cavalry and infantry. ${ }^{39}$ According to Polybius, the Roman formation was effective against the elephants, which concerned them most, but at the same time benefited the enemy cavalry, ${ }^{40}$ and thus Xanthippus benefited from it, ordering a simultaneous mahout and cavalry charge.

It cannot be said that one single factor was responsible for the Carthaginian victory. They had the advantage of choice of the battlefield, a seemingly moralized army and a strong line of elephants and cavalry. There was also the urge to defend the city, and the advantage of being in familiar territory. The Roman army was tired, in adverse conditions, and broken in half. The Battle of the Bagradas river seems to have been won not by the effect of a different training method (given Xanthippus had little time to train the army before it happened), and probably not even due to the formation adopted by the commander. The most important element seems to have been the cavalry, against which Rome could do nothing, not because of superior capacity among the Carthaginian cavalry (whether they were superior, it is not intended to discuss it here), but due to numeric superiority.

The Carthaginian generals won victories for centuries before the First Punic War, and throughout the war itself. They were not incapable: there were both Carthaginian victories and defeats during the Greco-Punic wars, and as the First Punic War began, Carthage had conquered several settlements both in Sicily and Sardinia, not to mention the North African territories and other Mediterranean islands. After the reforms of Mago, the structure of the army in battle became close to the Greek fighting style, so their tradition comes in a line not much different from Xanthippus'. Why did they allow a foreign commander, and how can History analyse the reported attempts on Xanthippus' life afterwards? There are several possible answers, and no means to confirm them. Perhaps Xanthippus was a well-known and popular general, whose feats were heard of across the Mediterranean mercenary contingents, and the Senate decided on requesting his help for a matter of moralisation. This hypothesis is hard to confirm, because the names of mercenary commanders are seldom recorded in History: the sources don't mention him before or after this event. Had the battle 
happened in Sicily, would his name have reached us?

As mentioned, the narration, at least in Polybius' Histories, is a literary device. Polybius seems to have recorded the episode with special attention, to use it as a source for moral reflections: the bybris of Regulus, his subsequent defeat and the importance of taking opportunities as they present themselves. ${ }^{41}$ Polybius' exploring of the theme might have induced him to pay special attention to the course of events in North Africa. Diodorus also seems to reflect upon the matter, much in the same way as Polybius, connecting History, Politics and the effects of leadership, with considerations on the case of Regulus, whom he classifies as arrogant. ${ }^{42} \mathrm{He}$ also speaks of Xanthippus in seemingly high regard, complimenting his capacities, remarking that, despite the seemingly unexpected victory, it was no surprise that an intelligent and well-experimented general could be successful. This does not account for other sources, though, given that most of them only mention his name, and don't take much heed of the morality of the matter. Asides from the former hypotheses, which are mostly related to a psychological and literary point of view, there is also a more practical observation. Carthaginian generals, just like any other commander in the Mediterranean, had subordinates, men who were in inferior ranks of the army but who were equally important in terms of practical command. Xanthippus may have been one of these men, second in command, whose name only gained special attention due to its particular circumstances and the shape of Polybius' narrative style. ${ }^{43}$

Whether literary device or a product of circumstances, Xanthippus does defeat the Roman army. The aftermath of the battle is very positive to Carthage. The Carthaginians had few losses, while Rome only had two-thousand survivors, according to Polybius. ${ }^{44}$ Many prisoners were made, including the consul, Regulus. Xanthippus had thus reached three achievements: he won the battle, prevented the Romans from reaching Carthage and was indirectly responsible for the Roman

41 Plb. 1.35.

42 D.S. 23.14.

43 During the Peloponnesian War (especially in the last years), it became frequent to write the names of officers falling in battle. There is a varied array of ranks amongst the lists of the fallen ("taxiarchs, a phrourarch, trierarchs and a mantis"). It seems unlikely that a list of the mercenary officers who fought in the First Punic War survived to this day, but, as seen previously, mercenaries sometimes inscribed their names. It is possible that, at some point, Xanthippus had his name registered. Wheeler 2002, 143.

44 Plb. 1.34. 
retreat from North Africa - indirectly, because even though he won a battle and demoralized the Roman army, the greatest hazard faced by the expedition was, as mentioned, the lack of supplies. From this moment onwards, Xanthippus' fate is a matter of speculation. Several hypotheses are presented, and most imply that his victory might have endangered him. Polybius says Xanthippus decided to leave the city soon afterwards, a decision Polybius classifies as well-thought and sensible, because his achievements would have been cause for envy, and he would not be able to secure his position, given he was a foreigner and had no friends or family to stand on his side. ${ }^{45} \mathrm{He}$ also says there are several accounts of Xanthippus' departure, and that he will get back to his case later, but he never does.

Some of these other versions might be found in different sources. Diodorus Siculus gives a longer account of his travels: he would have returned to Sparta, where he would have gathered fifty to one hundred soldiers, ${ }^{46}$ and then travelled to Sicily, ${ }^{47}$ where he would have offered his services to the Sicels. Another victory ensued, but the envious Sicels then set him in a leaking ship and let him drown in the Adriatic. A similar version is told by Cassius Dio, also regarding a ship. In the first version, the Carthaginians would have chased him after his departure and sunk his ship; in the other, very similar to the one told by Diodorus, he was given a ship in poor condition, but he would have realised it and boarded a different ship, saving himself. ${ }^{48}$ Appian says the Carthaginians made offers to him and his companions, and pretended to send him back to Sparta, having the captains of the ships throw him and his comrades to the sea. ${ }^{49}$

One thing most versions seem to have in common is the ending: but for one case, Xanthippus is always killed due to jealousy. In Diodorus, he seems to have

45 Silius Italicus, a $1^{\text {st }}$ century author, wrote an epic poem named Punica. In this work, he says Xanthippus came not of Sparta itself, but of the city of Amyclae, in Laconia (Punica, 2.432-436). Silius also says Xanthippus had three children by a Carthaginian woman. This woman was Leda Sidonia Barce, married to a Carthaginian, and he would have accepted the children as his. This story is not mentioned anywhere else. Xanthippus might have fathered children during his stay, but Silius seems to make a narrative device of the story (the symbolism of the number 3, and their combat against three Italian brothers of the same age).

46 D.S. 23.16. The number is uncertain, even according to Diodorus. He says there are several versions in different sources. The story of Xanthippus seems to have been well-known, and it is likely that some versions of it were lost.

47 This reinforces the idea of Xanthippus having already fought battles in Sicily. As a mercenary commander, he would probably have travelled with his militia across the Mediterranean, looking for warring parties who wished to hire his services. It would also explain his former knowledge of the Carthaginian army.

48 D.C. 11.13.

49 App. Pun. 1.4. 
reached Sparta, and in Appian he boarded a ship to his homeland, but never made it. However, he seems to have survived at least in the second version told by Dio, and Polybius too does not mention him being killed: even though he owns to there being different accounts of the story, he only mentions Xanthippus' departure of Carthage. In his account, the general also seems to have been well-aware of the negative effects the victory could bring upon him.

This raises several doubts. Xanthippus won a very large battle for Carthage, so one might wonder why the city would try to put an end to his life, instead of keeping him in his post throughout the rest of the war. The matter of jealousy is in fact mentioned, even though both the Senate and the Generals seem keen on allowing him to lead the army in the first place (there's even the hypothesis of them having requested a general to Sparta, instead of hiring Xanthippus as part of mercenary corps). But across the Mediterranean, and particularly in Sicilian history, there are several accounts of mercenaries deserting / attempting to desert the remainder of the army, betraying the $\mathrm{city}^{50}$. City leaders also knew the possible effects of allowing mercenary bands to be let lose in their territory: Rome, Carthage and Syracuse ${ }^{51}$ dealt with the case of the Mamertines, used as a pretext for engaging in war. There is also the matter of Xanthippus knowing the Carthaginian army quite well at this point, and most likely the territory.

But the main cause to the attempts on his life might have been yet another. Carthage had financial issues to support the war, something that is insinuated several times across the sources. One of the causes of the subsequent Mercenary War seems to have been the lack of payments, and Carthage might have worked in a system of "credit" or promises made, given that they hired new mercenaries to fight in the Mercenary War even though they had not the means to pay to former employed soldiers. In Xanthippus' case, there are two passages regarding payment: Appian mentions him having received presents, but Dio says Carthage had not enough wealth to pay the mercenaries what they were owed, and misled them to

50 This includes the First Punic War. One might mention the case of Alexon of Achaea, who seems to have done the opposite, preventing the mercenaries of leaving by warning the commanders; he did so at least two times, and was most likely rewarded. Plb. 1.43.

51 Hiero II even attempted to rid his domains from the Mamertines altogether, and his actions prompted the mercenary help request which stirred the war. Anderson 2005, 12. 
their deaths. The lack of funds might have been one of the determinant causes for Xanthippus' dismissal. It was not uncommon for Carthage to discharge its mercenaries whenever it could not find the resources to pay their wages. ${ }^{52}$

Did Xanthippus succumb to the Carthaginian or Sicel efforts? In the Ptolemy Chronicle, a man named Xanthippus is referred as being governor of Mesopotamia in 245 BCE, appointed by the pharaoh himself f $^{53}$. This Xanthippus was a military commander, involved in several operations across the territory. A few days post the action on the Bêlet Ninua Citadel, this man would have entered the temple of Marduk (Esagila) and performed offerings in the temple, which are cited as being made "in the Greek Fashion". He would have also eaten bread in a temple, which is thought to be another Greek custom. Xanthippus would have been responsible for besieging the royal palace of Babylon, still unconquered by the Ptolemaic army. In the commentary made to this chronicle, whose first reading is proposed by Bert van der Spek, the soldiers who fought in this situation would have been under Xanthippus' service, and would have been armed in the hoplite fashion, with an "iron panoply". ${ }^{54}$ This hypothesis of translation of line 6' (reverse) implies that the army fighting for Ptolemy was at least partially made of mercenaries. ${ }^{55}$

These events occurred during the Third Syrian War (246-241 BCE). The chronology matches the end of the First Punic War, and the battles mentioned in the Chronicle occur in the Middle East, under the service of an Egyptian Pharaoh. It might be a coincidence that a man with the same name and same activity is mentioned, but it cannot be disregarded that this might be the same Xanthippus who fought for Carthage near the Bagradas river. If he survived, he might have pursued his career as a mercenary commander, now with a new reference of his

52 Rawlings, quoting D.S. 5.11 and Zonar. 8.13, mentions the story of a «bony’ Island», known as Osteodes, whose name would be due to a high number of «human remains». Diodorus tells of a time when the war between Carthage and Syracuse created a great strain of human strength both in land and sea, thus increasing mercenary use. Six thousand mercenaries were not paid, so Carthage would have induced them to board a ship on the pretext of going on a mission, and subsequently dropped them in Osteodes, where they died of starvation. Zonaras states the same happened to the mercenary troops who fought in the Battle of the Bagradas River. Rawlings 2010, 268 and 284.

53 Ptolemy III Chronicle (Busayra Cultural Heritage Project 11). Sage mentions the increasing size of the Ptolemaic armies throughout the $4^{\text {th }}$ and $3^{\text {rd }}$ centuries BCE. Sage 2002b, 198.

54 Ptolemy III Chronicle: Comments to 5'6, 8'; Lines 1-14 Obverse and 1-15 Reverse; Summary of Month X.

55 The records show the presence of Greek mercenaries in Egypt since, at least, the mid of the $7^{\text {th }}$ century BCE. As mentioned by Hale, there are inscriptions in Abu Simbel, dating of the $6^{\text {th }}$ century BCE, which show the names of mercenaries coming from «eastern Greek islands and cities». He also mentions a «tradition» of Egyptian mercenary service amongst some Greek households. Hale 2013, 184-82. 
expertise. He could then pursue the circuits of war and, given the danger he might have been at returning to Sicily (or the Western Mediterranean as a whole, given that Carthage was influential across it), he could have turned to the conflicts in the East. ${ }^{56}$ If so, he would have improved his situation, becoming a governor and/or a trierarch. ${ }^{57}$ If indeed this is the same man, his achievements under Ptolemy III were lost in the Greco-Roman world. ${ }^{58}$ Until new records are found (if they are ever to be found), historians and archaeologists cannot know for certain. Even if he did fight for Ptolemy III, there is a gap of at least ten years between the Roman invasion of North Africa and the Third Syrian War, during which we know nothing of his life.

Whether he was killed by the actions of his employers, or survived to fight under Egyptian orders, the fact is that this commander was the most influential foreign warrior in the First Punic War, and maybe in Carthaginian history, but only when seen through the eyes of Roman Literature. He is the only one whose name reaches the sources, and seems to be the only mercenary officer to be allowed full command of the Carthaginian army, for the first and only time throughout the war and, perhaps, in the whole History of Carthage, but we have no Carthaginian sources to compare. Even though he is otherwise an obscure figure, his background is worthy of further studies and might bring reflections not only on the organisation and formation of the Carthaginian army of the mid-third century BCE, but also of the origins and formation of Greek mercenary armies, the impact of war in the Mediterranean, the economic, social and philosophical impact of war among the populations and, above all, the shaping of the morality of war in the Roman world.

56 Bevan $[1927] 2014,197$. Even though the book was written in the early $20^{\text {th }}$ century, the idea is quite valid nowadays.

57 There is a discussion on whether Xanthippus was the trierarch who paid "to rebuild or repair a nine". This theory is related to the evolution of the Ptolemaic navy, and is not to be discussed here. One can find information in Fischer-Bovet 2014, 71. Hauben 2013, 42. If it was Xanthippus, it means he was used to being a commander both in land and at sea.

58 As says Robert Waterfield in his comment to Plb. 1.36. 


\section{BIBLIOGRAPHY}

\section{Ancient Sources}

Cary, Earnest, trans. 1914. Cassius Dio. Roman History. Harvard: Loeb Classical Library.

Forster, Edward S., trans. 1929. Florus. Epitome of Roman History. Harvard: Loeb Classical Library.

Geer, Russel M., trans. 1945. Diodorus Siculus. The Library of Diodorus Siculus. Harvard: Loeb Classical Library.

Godley, Alfred D., trans. 1920. Herodotus. The Histories. Cambridge, MA: Harvard University Press.

Jones, H. L., trans. 1932. Strabo. The Geography. Harvard: Loeb Classical Library.

Marchant, E. C. and G. W. Bowersock, trans. 1968. Xenophon. "Constitution of the Lacedaemonians". Xenophon in Seven Volumes. Vol. 7. Cambridge, MA: Harvard University Press.

Miller, Walter, trans. 1913. Cicero. De Officiis. Harvard: Loeb Classical Library.

Page, T. E., E. Capps, W. H. D. Rouse, L. A. Post et E. H. Warmington, eds. 1961. Silius Italicus. Punica. 2 vols., trans. J. D. Duff. Cambridge MA: Harvard University Press.

Perrin, Bernardotte, trans. 1921. Plutarch. “The Life of Cleomenes”. Parallel Lives. Harvard: Loeb Classical Library. Spek, Bert van der., trans. 2003. Ptolemy III Chronicle (Busayra Cultural Heritage Project 11). URL.: http://www.livius. org/cg-cm/chronicles/bchp-ptolemy_iii/

Roberts, Canon, trans. 1912. Livy. History of Rome. New York: E. P. Dutton and co.

Walton, F. R., trans. 1957. Diodorus Siculus. The Library of Diodorus Siculus. Harvard: Loeb Classical Library.

Waterfield, Robert, trans. 2010. Polybius. Polybius: The Histories. Oxford: Oxford University Press.

White, Horace, trans. 1913. Appian. "The Punic Wars". The Roman History. Harvard: Loeb Classical Library.

\section{Modern Studies}

Anderson, Erich B. 2015. “The Rise of the Sons of Mars.” History Today 65 (3):11-17.

Atkinson, Kathleen M. T. Chrimes. (1949) 1999. "Relations with the Achaean League and Rome.” In Ancient Sparta: A Re-examination of the Evidence, 1-56. Manchester: Manchester University Press.

Bagnall, Nigel. 1999, “The African Campaign - 256-255 BC.” In The Punic Wars: Rome, Carthage and the Struggle for the Mediterranean, 70-79. London: Pimlico.

Bevan, Edwyn. (1927) 2014. "Ptolemy III., Eueergetes I (247-221 B.C.).” In A History of Egypt Under the Ptolemaic Dynasty, 189-317. New York: Routledge.

Bugh, Glenn Richard. 1988. "Aristocratic Horsemen of Archaic Athens.” In The Horsemen of Athens, 3-38. New Jersey: Princeton University Press.

Champion, Craige Brian. 2004. "Text and Narrative.” In Cultural Politics in Polybius's Histories, 67-172. Berkeley: University of California Press.

Chaniotis, Angelos. 2005. "War as a Profession: Officers, Trainers, Doctors, Engineers.” In War in the Hellenistic world: a social and cultural history, 78-102. Malden: Blackwell Publishing. 
2002. "Foreign Soldiers - Native girls? Constructing and Crossing Boundaries in Hellenistic Cities with Foreign Garrisons." In Army and Power in the Ancient World, eds. Angelos Chanoitis and Pierre Ducrey, 99-114. Stuttgart: Franz Steiner Verlag.

De Angelis, Franco. 2016. “Societies.” In Archaic and Classical Greek Sicily: A Social and Economic History, 134-222. New York: Oxford University Press.

Fischer-Bovet, Christelle. 2014. "The cost of an empire: financing land army and fleets." In Army and Society in Ptolemaic Egypt, 66-86. Cambridge: Cambridge University Press.

Gaebel, Robert E., 2002. “Conclusion.” In Cavalry Operations in the Ancient Greek. World, 277-311. Norman: University of Oklahoma Press.

Griffith, Guy Thompson. (1935) 2014. "The Greek Leagues and Cities." In The Mercenaries of the Hellenistic World, 80-107. Cambridge: Cambridge University Press.

Hale, John R. 2013. "Not Patriots, Not Farmers, Not Amateurs: Greek Soldiers of Fortune and the Origins of Hoplite Warfare." In Men of Bronze: Hoplite Warfare in Ancient Greece, eds. Donald R. Kagan and Gregory F. Viggiano, 176-93. Princeton: Princeton University Press.

Hauben, Hans. 2013. "Callicrates of Samos and Patroclus of Macedon, Champions of Ptolemaic thalassocracy." In The Ptolemies, The Sea and the Nile: Studies in Waterborne Power, eds. Kostas Buraselis, Mary Stefanou and Dorothy J. Thompson, 39-65. Cambridge: Cambridge University Press.

Hinge, George, 2003. "Scythian and Spartan Analogies in Herodotos' Representation: Rites of Initiation and Kinship Groups.” In The Cauldron of Ariantas: Studies presented to A. N. Šreglov on the occasion of his 70th birthday, eds. Pia Guldager Bilde, Jakob Munk Højte and Vladimir F. Stolba, 55-74. Aarhus: Aarhus Universitetsforlag. Hodkinson, Stephen. 2013. "Social Order and the Conflict of Values in Classical Sparta." In Sparta, ed. Michael Whitby, 104-30. London: Routledge.

Luraghi, Nino. 2006. “Traders, Pirates, Warriors: The Proto-History of Greek Mercenary Soldiers in the Eastern Mediterranean.” Phoenix 60 (1-2):21-47.

Miltsios, Nikos. 2013 “The narrative of the prokataskeue." In Trends in Classics - Supplementary Volumes: The Shaping of Narrative in Polybius, 30-58. Berlin: De Gruyter.

Oliver, G. J. 2011. "Mobility, Society and Economy in the Hellenistic Period." In The Economies of Hellenistic Societies - Third to First Centuries BC, eds. Zosia H. Archibald, John K. Davies and Vincent Gabrielsen, 345-67. Oxford: Oxford University Press.

Raven, Susan. (1969) 2012. “The Rise of Carthage.” In Rome in Africa (3). $3^{\text {rd }}$ ed., 17-33. London: Routledge.

Rawlings, Louis. 2010. “The Carthaginian Navy: Questions and Assumptions.” In History of Warfare: New Perspectives on Ancient Warfare (1), eds. Garrett Fagan and Michael Sage, 253-88. Leiden: Brill.

Sage, Michael. 2002a. "The Rise of Macedonia: Philip and Alexander." In Routledge Sourcebooks for the Ancient World: Warfare in Ancient Greece: A Sourcebook (1), 162-96. London: Routledge.

—. 2002b. "Hellenistic Warfare." In Routledge Sourcebooks for the Ancient World: Warfare in Ancient Greece: A Sourcebook (1), 197-28. London: Routledge.

1996. “The Age of Hoplite Warfare - Introduction.” In Warfare in Ancient Greece: A Sourcebook, 25-38. New York: Routledge. 
Snodgrass, Anthony. 2013. "Setting the Frame Chronologically." In Men of Bronze: Hoplite Warfare in Ancient Greece, eds. Donald Kagan and Gregory F. Viggiano, 85-94. New Jersey: Princeton University Press.

Trundle, Matthew. 2004. "Hiring Greek mercenaries." In Greek Mercenaries: From the Late Archaic Period to Alexander, 104-31. London: Routledge.

Wheeler, Everett L., 2002. “The General as Hoplite.” In Hoplites: The Classical Greek Battle Experience (1), ed. Victor Davis Hanson, 121-72. London: Routledge.

Wylie, Dan. 2009. “Using Elephants.” In Animal: Elephant, 114-52. London: Reaktion Books. 